\title{
The Role of Hope in Academic and Work Environments: An Integrative Literature Review
}

\author{
Vasiliki Yotsidi, Aggeliki Pagoulatou, Theodoros Kyriazos, Anastasios Stalikas \\ Department of Psychology, Panteion University of Political and Social Sciences, Athens, Greece \\ Email: vickyyotsidi@netscape.net
}

How to cite this paper: Yotsidi, V., Pagoulatou, A., Kyriazos, T., \& Stalikas, A. (2018). The Role of Hope in Academic and Work Environments: An Integrative Literature Review. Psychology, 9, 385-402. https://doi.org/10.4236/psych.2018.93024

Received: January 26, 2018

Accepted: March 25, 2018

Published: March 28, 2018

Copyright (c) 2018 by authors and Scientific Research Publishing Inc. This work is licensed under the Creative Commons Attribution International License (CC BY 4.0).

http://creativecommons.org/licenses/by/4.0/

\section{cc) (i) Open Access}

\begin{abstract}
The aim of this review was to present the most recent evidence on the interaction of hope with academic and work variables, since hope is increasingly recognized as an important psychological resource for academic achievement, career development and job performance. This paper included peer-reviewed research papers of the past five years, which were identified through searching Healink, Scopus and Google Scholar databases. We applied several combinations of relevant search terms (e.g. hope, academics, university, work, students and employees). Only English language studies were selected. Twenty-three research papers matched the inclusion criteria. Overall, the review found that hope plays a predictive role in academic and job performance, while hope correlates positively with several variables related to task accomplishment and well-being. The practical value of the findings in academics and the workplace is discussed and further recommendations are provided based on the review.
\end{abstract}

\section{Keywords}

Hope, Academics, Career Development, Work Performance, Leadership

\section{Introduction}

Hope has been traditionally conceptualized in social sciences in a variety of ways, such as basic trust (Erikson, 1950), conditioned response (Mowrer, 1960), goal expectations (Stotland, 1969), or spiritual attachment (Pruyser, 1987). Nevertheless, the most recent and widespread theory of hope resides in the field of Positive Psychology (Snyder et al., 1991). Particularly, hope is included among the twenty-four core character strengths, since it reflects a person's expectation of his/her best possible outcome and the concomitant work to achieve it (Peter- 
son \& Seligman, 2004). According to Snyder (2002), hope is a positive motivational state that is based on an interactively derived sense of successful 1) agency (goal-directed energy), and 2) pathways (planning to meet goals). Hence, hopeful thinking is goal-oriented and it reflects both situational and trait-like thinking processes with emotions playing an important and contributory role (Snyder, 2002).

Agency thinking, as the first component of hopeful thinking, is the perceived capacity to use one's pathways to reach the desired goals and thus it represents the motivational component of the hope theory (Snyder, 2002). These self-referential thoughts involve the mental energy to begin and continue an effort using a pathway through all stages of the goal pursuit. High-hope people embrace self-talk agency phrases such as, "I can do this", or "I am not going to be stopped" (Snyder, LaPointe, Jeffrey Crowson, \& Early, 1998). Agency thinking is important in all goal-directed thought, but it takes on special significance when people encounter impediments. During blockages, agency helps people to channel the requisite motivation to the best alternative pathway (Snyder, 1994).

Pathways, as the second component of hope, reflect the means to reach someone's objectives and entail the thoughts of generating usable routes to meet the desirable goals. Pathways thinking became increasingly refined and precise as the goal pursuit sequence progresses toward the goal attainment (Snyder, 2002). As it was empirically supported, high- as compared to low-hope persons were more decisive and confident about the production of a plausible route for pursuing a specific goal, especially with regard to career goals (Woodbury, 1999).

Pathways and agency thinking constantly interact, while emotions play a functional role in this process. Particularly, as the goal pursuit proceeds, the person may encounter a stressor, which represents an impediment of sufficient magnitude to jeopardize hopeful thought (Snyder, 2002). Low-hope persons are especially susceptible to succumbing to stressors and becoming derailed in their goal pursuits. For a high-hope person, however, the stressor is seen as a challenge (Snyder et al., 1991) that may necessitate alternative pathways and rechanneling of agency to a new pathway. Furthermore, under conditions of goal non-attainment and subsequent negative emotions, it has been found that highas compared to low-hope persons are better able to use feedback to improve their goal pursuit thoughts and strategies for that same situation, should it be encountered in the future (Snyder, 2002). On the other hand, in case of low-hope thinking the feedback from goal non-attainments is not used diagnostically to improve future efforts, but it instead produces rumination and self-doubt (Michael, 2000).

Human actions are goal-directed. As such, any behavior in work and academic environments that is related to task accomplishment should be considered as a goal. Nevertheless, the academic field and the workplace have only recently been areas of scientific interest in relation to the hope theory. Previous research indi- 
cated that hope was associated with superior academic performance (Snyder, Cheavens, \& Michael, 1999), while the Adult Hope Scale was found to have predictive value for GPAs and academic results (Snyder, 2002). This was attributed to the benefits that high-hope students had of finding multiple pathways to desired educational goals and being able to attend to the appropriate cues in learning and testing environments (Snyder, 2002). More specifically, previous research suggested that hope was related to coping and problem solving, since high-hope students employed significantly less disengagement strategies than low-hope students in stressful academic situations (Chang, 1998). In addition, it has been demonstrated that the predictive value of hope for higher GPAs remained significant when controlling for students' general intelligence, divergent thinking, personality, and previous academic achievement (Day, Hanson, Maltby, Proctor, \& Wood, 2010). Similarly, it was suggested that hope should play an important role in employees' job performance (Peterson \& Byron, 2008). More hopeful employees are expected to be prepared for and interpret success and failure differently than less hopeful employees, since higher hope individuals conceive of many strategies to reach their goals and plan contingencies in the event that they are faced with impediments along the way, while low hope individuals are more likely to disengage from their goals (Peterson \& Byron, 2008).

With the aim of inviting further scientific inquiry on the role of hope in academic and job environments, we reviewed the most recent literature on the benefits of hope for academic and occupational success. The questions we posed in this review are the following: 1 ) which academic and work variables interact with hope, and 2) what is the nature of this interaction (i.e. correlational, predictive, mediational or moderating). Integrating in a joint review the available current evidence on the role of hope in academic and work environments can inform efforts to improve future research studies as well as best practices for career counseling and personnel development purposes.

\section{Method}

\subsection{Eligibility Criteria}

We searched the literature using the inclusion criteria presented in Table 1. Particularly, we included any kind of quantitative study design (e.g. cross-sectional, longitudinal), which reported on hope and academics, job or workplace from January 2011 until December 2016. Book chapters, reviews, qualitative studies and non-peer reviewed grey literature or incomplete surveys were excluded. For

Table 1. Eligibility criteria of studies in the review.

\begin{tabular}{llll}
\hline \multicolumn{1}{c}{ Type of studies } & \multicolumn{1}{c}{ Type of participants } & \multicolumn{1}{c}{ Type of methods } \\
\hline & & University/college students & - Hope scales \\
- Quantitative study design & - & Academics & Hope as a main or \\
- Published from 2011 to 2016 & - Employees & secondary variable \\
- English papers & - & Employers or managers & Work or academic \\
& & variables \\
\hline
\end{tabular}


practical reasons, the papers had to be written in English.

Studies in which the participants were university/college students, employees, employers or leaders in a workplace regardless of their profession, field of studies or origin were examined. There was only one study with homeless women as participants, which was included, as it investigated the role of hopeful thinking in predicting the women's expected capabilities to obtain employment. Studies that measured the variable of hope using the existed hope scales in any version were included. Hope could be the main variable or could be measured along with other variables related to work and academic issues.

\subsection{Search Strategy, Study Selection and Data Extraction}

To identify relevant peer-reviewed literature, we searched the following search engines: Healink, Scopus and Google Scholar, as these databases are the most extensive ones in the field of social sciences. Literature was searched with the following algorithms: "hope" AND “academics" (OR "university" OR “college" OR “students" OR “academicians" OR "tertiary education") and "hope" AND “workplace” (OR “job” OR “work” OR “employment” OR “career” OR “employees" OR “workers” OR “employers” OR “managers”). The studies were first selected on the basis of their title and abstract. Following that, each of the titles and abstracts were assessed by two independent reviewers. Any paper that was considered to be relevant by either of the two reviewers was included for full-text review. Full-text papers were then screened by two independent reviewers and a consensus was made among them as to whether the paper met the inclusion criteria. We started our search from 2011 onwards because the aim of our review was to present the most recent evidence in the field, taking also into account that the accumulated up-to-date knowledge about the empirically supported effects of the positive variable of hope on work and academic environments would be of added value in the current difficult period of the global economic crisis. After searching with these criteria, the relative results to our subject were finally thirty studies. Papers that did not provide primary data, such as meta-analyses and systematic reviews and papers finally assessed as irrelevant to our subject, were excluded. In total, 23 papers were included to be reviewed.

\section{Results}

The results of all the twenty-three studies that were found in the literature were separated in three sub-groups: 1) studies on hope in the academic environment (Table 2), 2) studies on hope with regard to the work environment, specific professions and career-related variables (Table 3), and 3) studies about leadership in workplace and its relationship with employees' performance (Table 4).

According to the findings of the studies in academic settings, the personal trait of hope predicted both academic hope and academic self-efficacy, and it indirectly predicted GPAs. This was also the case of the longitudinal study, where hope was found to be a predictor of academic achievement across all the four 
Table 2. Overview of quantitative data studies in academic environment included in the review.

\begin{tabular}{|c|c|c|c|c|c|c|}
\hline Reference & $\begin{array}{l}\text { Study } \\
\text { Design }\end{array}$ & Variables & Data collection tools & Issue of study & Sample & Summary of findings \\
\hline $\begin{array}{l}\text { Feldman \& } \\
\text { Kubota } \\
(2015)\end{array}$ & Cross-sectional & $\begin{array}{l}\text { Hope, general } \\
\text { self-efficacy, } \\
\text { optimism, } \\
\text { GPAs, academic } \\
\text { hope, academic } \\
\text { self-efficacy }\end{array}$ & $\begin{array}{l}\text { Adult Hope Scale (AHS), } \\
\text { Domain-Specific Hope } \\
\text { Scale (DSHS), General } \\
\text { Self-Efficacy Scale } \\
\text { (GSES), Academic } \\
\text { Self-Efficacy Scale } \\
\text { (ASES), Life Orientation } \\
\text { Test-Revised (LOT-R) }\end{array}$ & $\begin{array}{l}\text { To test a path-analytic } \\
\text { model including } \\
\text { academic specific and } \\
\text { generalized } \\
\text { expectancies, GPAs } \\
\text { and academic } \\
\text { specific variables. }\end{array}$ & $\begin{array}{l}89 \text { college } \\
\text { students }\end{array}$ & $\begin{array}{l}\text { General hope predicted } \\
\text { academic hope and } \\
\text { academic hope directly } \\
\text { predicted GPAs. General } \\
\text { hope predicted academic } \\
\text { self-efficacy, which in turn } \\
\text { predicted GPAs. }\end{array}$ \\
\hline $\begin{array}{l}\text { Sharabi, } \\
\text { Sade, \& } \\
\text { Margalit } \\
(2016)\end{array}$ & Cross-sectional & $\begin{array}{c}\text { Students' } \\
\text { learning } \\
\text { disabilities (LD), } \\
\text { Internet and } \\
\text { smart-phone } \\
\text { activities, } \\
\text { hope, optimism, } \\
\text { sense of } \\
\text { coherence (SOC), } \\
\text { loneliness, } \\
\text { academic } \\
\text { self-efficacy }\end{array}$ & $\begin{array}{l}\text { Loneliness scale, ASES, } \\
\text { Internet social, pleasure, } \\
\text { interpersonal and } \\
\text { avoidance coping } \\
\text { subscales, Smartphone's } \\
\text { amount and social } \\
\text { subscales, State Hope } \\
\text { Scale, LOT-R, SOC }\end{array}$ & $\begin{array}{l}\text { To examine (a) } \\
\text { differences between } \\
\text { students with and } \\
\text { without LD and (b) } \\
\text { predicting factors to } \\
\text { students' loneliness and } \\
\text { academic self-efficacy. }\end{array}$ & $\begin{array}{l}178 \text { female college } \\
\text { students in two } \\
\text { groups ( } 59 \text { with \& } \\
119 \text { without LD) }\end{array}$ & $\begin{array}{l}\text { Higher level of loneliness } \\
\text { and lower levels of ASES in } \\
\text { students with LD. Internet } \\
\text { use for avoidance coping as a } \\
\text { significant predictor for } \\
\text { loneliness and ASES. } \\
\text { LD was positively } \\
\text { associated with online } \\
\text { avoidance coping. }\end{array}$ \\
\hline $\begin{array}{l}\text { Gallagher, } \\
\text { Marques, \& } \\
\text { Lopez } \\
(2017)\end{array}$ & Longitudinal & $\begin{array}{l}\text { Semesters } \\
\text { enrolled, } \\
\text { GPAs, hope, } \\
\text { engagement, } \\
\text { academic } \\
\text { self-efficacy }\end{array}$ & $\begin{array}{l}\text { DSHS, ASES, Gallup } \\
\text { College Student } \\
\text { Engagement Scale } \\
\text { (GCSES) }\end{array}$ & $\begin{array}{l}\text { The role of hope in } \\
\text { predicting academic } \\
\text { achievement in college. }\end{array}$ & $\begin{array}{l}229 \text { students } \\
\text { (across their } 4 \\
\text { college years) }\end{array}$ & $\begin{array}{l}\text { Hope, self-efficacy and } \\
\text { engagement were correlated } \\
\text { with the number of semesters } \\
\text { and GPAs. Hope was the only } \\
\text { factor that had unique } \\
\text { effects when examining } \\
\text { predictors and controlling } \\
\text { for academic history. }\end{array}$ \\
\hline $\begin{array}{l}\text { Sung, } \\
\text { Turner, \& } \\
\text { Kaewchinda } \\
\text { (2011) }\end{array}$ & Cross-sectional & $\begin{array}{c}\text { Hope, } \\
\text { educational and } \\
\text { career skills, } \\
\text { educational and } \\
\text { career outcome }\end{array}$ & $\begin{array}{c}\text { AHS, mean of } \\
\text { participants' math, } \\
\text { science, and language } \\
\text { grades, Structured } \\
\text { Career Development } \\
\text { Inventory (SCDI) }\end{array}$ & $\begin{array}{c}\text { Relationships between } \\
\text { hope and educational } \\
\text { and career skills and } \\
\text { outcomes. }\end{array}$ & $\begin{array}{l}132 \text { students } \\
\text { from a public } \\
\text { university }\end{array}$ & $\begin{array}{l}\text { The agency aspect of hope } \\
\text { predicted both skills and } \\
\text { outcomes; skills or } \\
\text { outcomes predicted } \\
\text { agency. Pathways were } \\
\text { not predictive, or predicted, } \\
\text { by skills or outcomes. }\end{array}$ \\
\hline $\begin{array}{c}\text { Drysdale } \\
\text { \& McBeath } \\
(2014)\end{array}$ & Cross-sectional & $\begin{array}{l}\text { Type of } \\
\text { education, } \\
\text { gender, faculty, } \\
\text { hope, } \\
\text { self-efficacy, } \\
\text { procrastination, } \\
\text { study skills }\end{array}$ & $\begin{array}{c}\text { Trait Hope Scale (THS), } \\
\text { Procrastination } \\
\text { Assessment } \\
\text { Scale-Students (PASS), } \\
\text { College Academic } \\
\text { Self-Efficacy Scale } \\
\text { (CASES), Learning and } \\
\text { Study Strategies } \\
\text { Inventory (LASSI) }\end{array}$ & $\begin{array}{l}\text { Relationships between } \\
\text { participation in } \\
\text { cooperative education } \\
\text { and several } \\
\text { psychological } \\
\text { constructs related to } \\
\text { success in both } \\
\text { academic and } \\
\text { professional settings. }\end{array}$ & $\begin{array}{c}1224 \\
\text { undergraduate } \\
\text { "cooperative" } \\
\text { students and } 746 \\
\text { "non-cooperative" } \\
\text { students }\end{array}$ & $\begin{array}{c}\text { Females scored } \\
\text { higher on hope scale. } \\
\text { No significant main } \\
\text { effect of cooperative } \\
\text { education for hope, } \\
\text { self-efficacy, } \\
\text { procrastination. }\end{array}$ \\
\hline
\end{tabular}

years of studies, while hope uniquely predicted the number of enrolled semesters as well (Gallagher, Marques, \& Lopez, 2017). Furthermore, with regard to the two core components of hope (i.e., agency and pathways) the results showed that the agency aspect of hope predicted both skills and outcomes, while skills or 
Table 3. Overview of quantitative data studies in work environment included in the review.

\begin{tabular}{|c|c|c|c|c|c|c|}
\hline Reference & $\begin{array}{l}\text { Study } \\
\text { design }\end{array}$ & Variables & Data collection tools & Issue of study & Sample & Results \\
\hline $\begin{array}{c}\text { Sezgin \& } \\
\text { Erdogan }(2015)\end{array}$ & Cross-sectional & $\begin{array}{l}\text { Academic } \\
\text { optimism, hope, } \\
\text { zest for work, } \\
\text { self-efficacy, } \\
\text { perceived } \\
\text { success }\end{array}$ & $\begin{array}{l}\text { Teachers' Sense of } \\
\text { Efficacy Scale } \\
\text { (TSES), Perceived } \\
\text { Success Scale (PSS), } \\
\text { Teacher Academic } \\
\text { Optimism Scale } \\
\text { (TAOS), Hope Scale } \\
\text { (HS), Zest for Work } \\
\text { Scale (ZWS) }\end{array}$ & $\begin{array}{l}\text { To examine the direct } \\
\text { and indirect predictive } \\
\text { powers of academic } \\
\text { optimism, hope, zest } \\
\text { for work on teachers' } \\
\text { self-efficacy and } \\
\text { perceived success. }\end{array}$ & $\begin{array}{c}600 \text { teachers from } 27 \\
\text { primary schools in } \\
\text { Turkey }\end{array}$ & $\begin{array}{l}\text { Significant } \\
\text { positive } \\
\text { relationships } \\
\text { among teachers' } \\
\text { self-efficacy, } \\
\text { perceived success, } \\
\text { academic } \\
\text { optimism, } \\
\text { hope and zest } \\
\text { for work }\end{array}$ \\
\hline $\begin{array}{l}\text { Reis \& } \\
\text { Hoppe } \\
(2015)\end{array}$ & $\begin{array}{l}\text { Two-wave } \\
\text { online survey } \\
\text { with a five } \\
\text { month } \\
\text { time lag }\end{array}$ & $\begin{array}{l}\text { Affective } \\
\text { well-being, } \\
\text { hope, emotional } \\
\text { demands and } \\
\text { autonomy } \\
\text { (perceived job } \\
\text { characteristics) }\end{array}$ & $\begin{array}{l}\text { WHO Well-being } \\
\text { Index, four items } \\
\text { (hope) from the } \\
\text { short version of the } \\
\text { Psychological } \\
\text { Capital } \\
\text { Questionnaire } \\
\text { (PCQ), Dutch } \\
\text { Questionnaire on } \\
\text { Work Experience }\end{array}$ & $\begin{array}{c}\text { To investigate (a) } \\
\text { whether baseline levels } \\
\text { and change in } \\
\text { affective well-being } \\
\text { are related to change } \\
\text { in emotional demands } \\
\text { and autonomy (b) the } \\
\text { mediating role of } \\
\text { hope. }\end{array}$ & $\begin{array}{c}326 \\
\text { psycho-therapists }\end{array}$ & $\begin{array}{l}\text { Baseline levels of } \\
\text { and change in } \\
\text { affective } \\
\text { well-being were } \\
\text { associated with } \\
\text { change in } \\
\text { emotional } \\
\text { demands. Change } \\
\text { in hope mediated } \\
\text { the effect of } \\
\text { change in } \\
\text { affective } \\
\text { well-being or } \\
\text { change in } \\
\text { autonomy }\end{array}$ \\
\hline Hirschi (2014) & Cross-sectional & $\begin{array}{l}\text { Dispositional } \\
\text { hope, career } \\
\text { planning, } \\
\text { decidedness, } \\
\text { self-efficacy, } \\
\text { proactive career } \\
\text { behaviors, } \\
\text { life- and } \\
\text { job-satisfaction }\end{array}$ & $\begin{array}{c}\text { THS, career } \\
\text { planning, } \\
\text { vocational } \\
\text { identity scale, } \\
\text { occupational } \\
\text { self-efficacy scale, } \\
\text { career engagement } \\
\text { scale, Satisfaction } \\
\text { with Life Scale } \\
\text { (SWLS), brief index } \\
\text { of affective job } \\
\text { satisfaction }\end{array}$ & $\begin{array}{l}\text { To investigate (a) } \\
\text { how hope is related } \\
\text { to career decidedness, } \\
\text { planning, and } \\
\text { self-efficacy beliefs } \\
\text { and (b) whether career } \\
\text { attitudes mediate the } \\
\text { effects of hope on } \\
\text { proactive career } \\
\text { behaviors, life-, and } \\
\text { job-satisfaction }\end{array}$ & $\begin{array}{c}1334 \text { university } \\
\text { students, } 233 \\
\text { employees }\end{array}$ & $\begin{array}{c}\text { Hope was } \\
\text { significantly } \\
\text { related, but } \\
\text { distinct, from } \\
\text { career variables. } \\
\text { Hope had a direct } \\
\text { effect on students' } \\
\text { proactive career } \\
\text { behaviors as well } \\
\text { as direct and } \\
\text { indirect effects on } \\
\text { students' life } \\
\text { satisfaction and } \\
\text { employees' job } \\
\text { satisfaction }\end{array}$ \\
\hline $\begin{array}{c}\text { Valero, } \\
\text { Hirschi, \& Strauss } \\
\text { (2015) }\end{array}$ & Cross-sectional & $\begin{array}{c}\text { Hope, } \\
\text { autonomous } \\
\text { goals, positive } \\
\text { affect, } \\
\text { self-efficacy, job } \\
\text { performance, } \\
\text { turnover, core } \\
\text { self-evaluations }\end{array}$ & $\begin{array}{l}\text { Children's hope } \\
\text { scale, autonomous } \\
\text { goals, multi-affect } \\
\text { indicator, short } \\
\text { occupational SES, } \\
\text { job performance } \\
\text { measure, turnover } \\
\text { intentions measure, } \\
\text { CSE scale }\end{array}$ & $\begin{array}{l}\text { To evaluate whether } \\
\text { hope affects job } \\
\text { performance and } \\
\text { turnover intention } \\
\text { through goals, positive } \\
\text { affective experience, } \\
\text { and occupational } \\
\text { self-efficacy beliefs }\end{array}$ & $\begin{array}{l}590 \text { Swiss adolescents } \\
\text { (apprentices) in } \\
\text { vocational training }\end{array}$ & $\begin{array}{l}\text { Hope was } \\
\text { positively related } \\
\text { to all three } \\
\text { motivational } \\
\text { states and } \\
\text { supervisor-rated } \\
\text { job performance } \\
\text { and negatively } \\
\text { related to } \\
\text { turnover } \\
\text { intentions }\end{array}$ \\
\hline
\end{tabular}




\section{Continued}

\begin{tabular}{|c|c|c|c|c|c|c|}
\hline $\begin{array}{l}\text { Santilli, Nota, } \\
\text { Ginevra, \& Soresi } \\
(2014)\end{array}$ & Cross-sectional & $\begin{array}{c}\text { Career } \\
\text { adaptability, } \\
\text { hope, } \\
\text { life-satisfaction }\end{array}$ & $\begin{array}{c}\text { Career } \\
\text { Adaptabilities } \\
\text { Scale-Italian } \\
\text { Form, THS, SWLS }\end{array}$ & $\begin{array}{l}\text { To investigate the role } \\
\text { of hope and career } \\
\text { adaptability in } \\
\text { affecting life } \\
\text { satisfaction of } \\
\text { workers with } \\
\text { intellectual disability }\end{array}$ & 120 adult workers & $\begin{array}{l}\text { Career } \\
\text { adaptability } \\
\text { indirectly, } \\
\text { through agency } \\
\text { and pathways, } \\
\text { predicted life } \\
\text { satisfaction }\end{array}$ \\
\hline $\begin{array}{l}\text { Malinowski \& } \\
\text { Lim (2015) }\end{array}$ & Cross-sectional & $\begin{array}{l}\text { Mindfulness, } \\
\text { work } \\
\text { engagement, } \\
\text { mental } \\
\text { wellbeing, } \\
\text { psychological } \\
\text { capital, } \\
\text { positive affect }\end{array}$ & $\begin{array}{c}\text { Five-Facet } \\
\text { Mindfulness } \\
\text { Questionnaire } \\
\text { (FFMQ), Utrecht } \\
\text { Work Engagement } \\
\text { Scale (UWES-9), } \\
\text { WEMWBS, PCQ, } \\
\text { Job-related Affective } \\
\text { Well-being Scale } \\
\text { (JAWS) }\end{array}$ & $\begin{array}{l}\text { To investigate the } \\
\text { relationship between } \\
\text { dispositional } \\
\text { mindfulness, work } \\
\text { engagement, and } \\
\text { well-being }\end{array}$ & $\begin{array}{l}229 \text { adults in full-time } \\
\text { employment }\end{array}$ & $\begin{array}{l}\text { Mindfulness } \\
\text { predicted work } \\
\text { engagement } \\
\text { and general } \\
\text { well-being. These } \\
\text { relationships were } \\
\text { mediated by } \\
\text { positive } \\
\text { job-related } \\
\text { affect and } \\
\text { psychological } \\
\text { capital }\end{array}$ \\
\hline $\begin{array}{l}\text { Sun, Zhao, Yang, } \\
\text { \& Fan, (2012) }\end{array}$ & Cross-sectional & $\begin{array}{l}\text { PsyCap, job } \\
\text { embeddedness, } \\
\text { job } \\
\text { performance }\end{array}$ & $\begin{array}{l}\text { Job embeddedness } \\
\text { seven-item scale, } \\
\text { PCQ, five-item scale } \\
\text { to measure in-role } \\
\text { performance }\end{array}$ & $\begin{array}{l}\text { To explore the } \\
\text { relationships between } \\
\text { PsyCap, job } \\
\text { embeddedness and } \\
\text { performance in nurses }\end{array}$ & $\begin{array}{c}733 \text { nurses from } \\
\text { five university } \\
\text { hospitals in China. }\end{array}$ & $\begin{array}{l}\text { A strong } \\
\text { relationship } \\
\text { between the } \\
\text { nurses' } \\
\text { self-reported } \\
\text { psychological } \\
\text { capital, job } \\
\text { embeddedness } \\
\text { and performance }\end{array}$ \\
\hline $\begin{array}{l}\text { Rego, Sousa, } \\
\text { Marques, \& } \\
\text { Cunha (2012) }\end{array}$ & Cross-sectional & $\begin{array}{c}\text { Self-efficacy, } \\
\text { hope, positive } \\
\text { affect, creativity } \\
\text { at work }\end{array}$ & $\begin{array}{l}\text { Six item self-efficacy } \\
\text { scale, SHS, Job } \\
\text { Affect Scale, } 13 \text { item } \\
\text { creativity scale }\end{array}$ & $\begin{array}{l}\text { To examine whether } \\
\text { self-efficacy and hope } \\
\text { predict creativity of } \\
\text { retail employees }\end{array}$ & $\begin{array}{l}507 \text { retail employees } \\
\text { and their supervisors }\end{array}$ & $\begin{array}{c}\text { Hope, self-efficacy } \\
\text { and positive affect } \\
\text { predicted } \\
\text { creativity. } \\
\text { Positive affect } \\
\text { partially mediated } \\
\text { the relationship } \\
\text { between hope and } \\
\text { self-efficacy with } \\
\text { creativity }\end{array}$ \\
\hline $\begin{array}{c}\text { Badran \& } \\
\text { Youssef-Morgan } \\
(2015)\end{array}$ & Cross-sectional & $\begin{array}{l}\text { Hope, efficacy, } \\
\text { resilience, } \\
\text { optimism, } \\
\text { PsyCap, job } \\
\text { satisfaction }\end{array}$ & $\begin{array}{c}\text { PCQ, SHS, Role } \\
\text { Breadth } \\
\text { Self-Efficacy Scale, } \\
\text { Ego-Resiliency } \\
\text { Scale, LOT-R, job } \\
\text { satisfaction measure }\end{array}$ & $\begin{array}{l}\text { The relevance of } \\
\text { PsyCap is } \\
\text { conceptualized and } \\
\text { tested in relation to } \\
\text { job satisfaction in } \\
\text { some of Egypt's most } \\
\text { important industries }\end{array}$ & $\begin{array}{l}451 \text { Egyptian } \\
\text { employees in } 11 \\
\text { organizations }\end{array}$ & $\begin{array}{c}\text { Hope, } \\
\text { self-efficacy, } \\
\text { resilience and } \\
\text { optimism, } \\
\text { individually and } \\
\text { when integrated } \\
\text { into the } \\
\text { higher-order } \\
\text { multidimensional } \\
\text { construct, } \\
\text { PsyCap, were } \\
\text { positively related } \\
\text { to employees' job } \\
\text { satisfaction }\end{array}$ \\
\hline
\end{tabular}




\section{Continued}

Bergheim, Eid,

Hystad, Nielsen, Mearns, Larsson,

\& Luthans (2013)

Paterson,

Luthans, \&

Jeung (2013)

Karatepe (2014) Cross-sectional
2 cross-sectional studies
Cross-sectional
PsyCap, safety climate, positive and negative affect
PCQ, Nordic questionnaire on work-related safety in the building and construction business, PANAS

10-item measure of thriving at work,

Thriving, agentic work behaviors,

Psychological capital, supervisor support, work performance

Hope, work engagement, job and service recovery performance, extra-role customer service four questions to measure attention at work, PCQ, five items from the organizational climate measure, four items from the in-role performance subscale

THS, short version of the Utrecht WE scale, five items to measure JP, Five items for operationalizing SRP, ERCS
To examine if the

PsyCap of

Norwegian air

traffic controllers

is related to their

perceptions

of safety

climate.

Study 1:

association

of PsyCap with

safety climate.

Study 2:

control for the mediation of positive and negative affect

To test thriving at work with self-development, agentic work behaviors, PsyCap and supervisor support climate as antecedent variables

To test whether work engagement mediates the effect of hope on job performance, service recovery performance, and extra-role customer service
Study 1: 77 air traffic controllers Study 2: 38 air traffic controllers from eight additional centers aditional centers

Study 1: PsyCap was positively correlated with safety climate.

PsyCap

explained

$31 \%$ of the

variance in

safety climate.

Study 2:

Controlling

for mediating effects of

positive and

negative

emotions,

PsyCap

explained

$15.5 \%$ of the

variance

PsyCap

positively

correlated

with all

variables.

Thriving at

work was

positively

related to

employee-supervisor dyads

supervisor-rated

employee

development

at work.

Thriving

led to better

performance

and development

Structural

Equation

Modeling

suggested that

the impact of

hope on job

110 full-time performance,

service

recovery

employees

and their managers

performance, and extra-role

customer

service was

fully

mediated

by work

engagement 


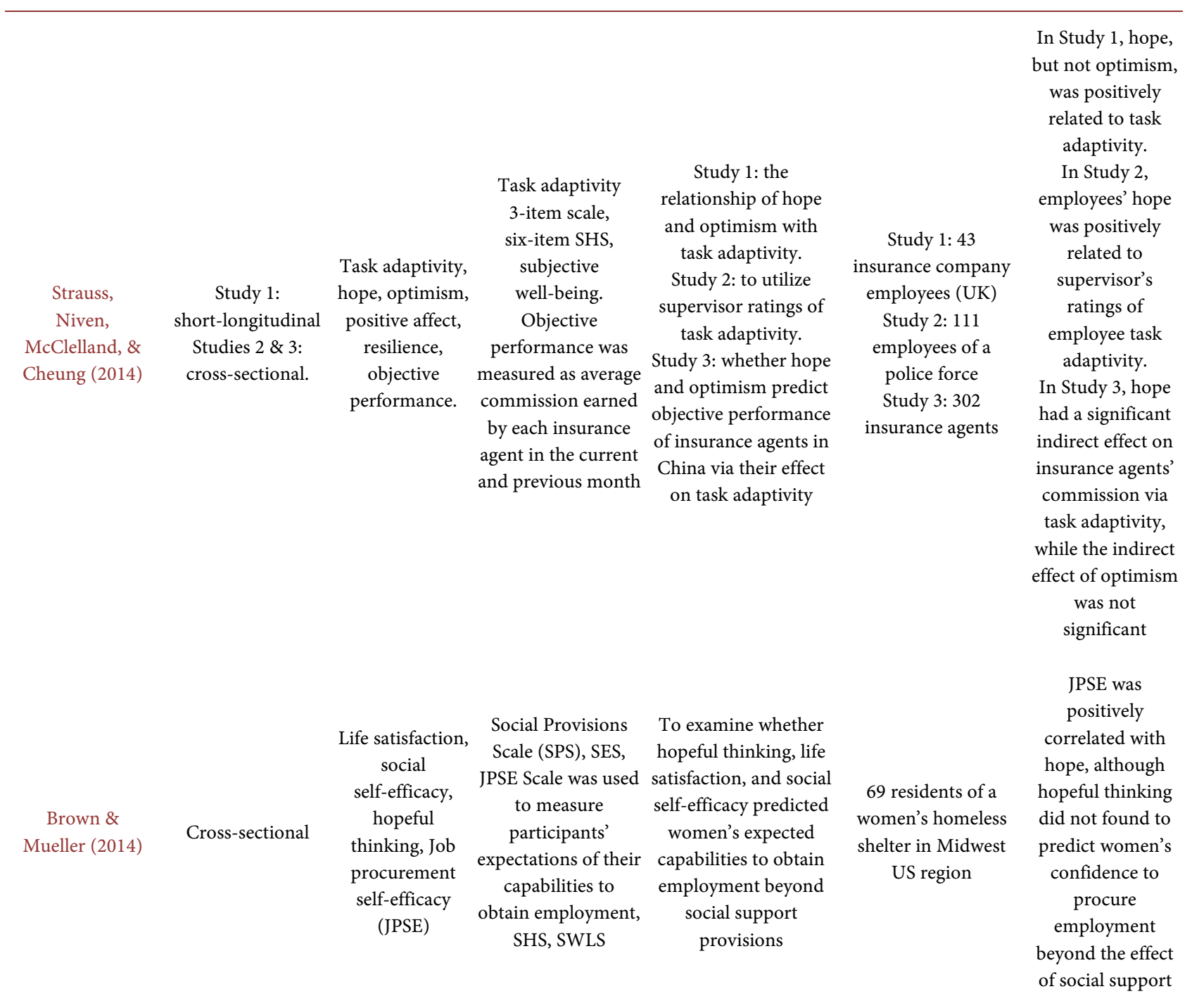

outcomes also predicted agency, indicating that there is a two-way relationship among these variables (Sung, Turner, \& Kaewchinda, 2011). Additionally, female students were found to score higher at hope than male ones, while the type of education (i.e., cooperative or traditional/non-cooperative) was not found to play an important role on the levels of hope (Drysdale, \& McBeath, 2014). In the case of students with learning difficulties, hopeful thinking was found to have a significant mediation effect between learning difficulties and students' online avoidance coping. Particularly, students with learning difficulties who had hopeful thinking were less engaged in avoidance coping through the Internet compared to their peers without hopeful thinking (Sharabi, Sade, \& Margalit, 2016).

Findings from the studies on hope and work-related variables indicated that hope was associated with employees' job satisfaction, performance, adaptivity, creativity, and feelings of efficacy and well-being. Particularly, hope was found 
Table 4. Overview of quantitative data studies on leadership included in the review.

\begin{tabular}{|c|c|c|c|c|c|c|}
\hline Reference & $\begin{array}{l}\text { Study } \\
\text { design }\end{array}$ & Variables & Data collection tools & Issue of study & Sample & Results \\
\hline $\begin{array}{l}\text { Rego, } \\
\text { Sousa, } \\
\text { Marques, } \\
\text { \& Cunha } \\
(2012)\end{array}$ & Cross-sectional & $\begin{array}{l}\text { Authentic } \\
\text { Leadership } \\
\text { (AL), PsyCap, } \\
\text { employees' } \\
\text { creativity }\end{array}$ & $\begin{array}{l}\text { Authentic Leadership } \\
\text { Questionnaire (ALQ), } \\
\text { PCQ, four items for } \\
\text { employees' creativity }\end{array}$ & $\begin{array}{l}\text { To examine whether } \\
\text { PsyCap is a predictor } \\
\text { of creativity, AL is a } \\
\text { predictor of } \\
\text { employees' PsyCap, } \\
\text { and PsyCap is a partial } \\
\text { mediator of the } \\
\text { relationship between } \\
\text { AL and creativity }\end{array}$ & $\begin{array}{l}201 \text { employees } \\
\text { and their } \\
\text { supervisors in } \\
33 \text { commerce } \\
\text { organizations } \\
\text { in Portugal }\end{array}$ & $\begin{array}{l}\text { Authentic leadership predicts } \\
\text { employees' creativity, both } \\
\text { directly and through the } \\
\text { mediating role of employees' } \\
\text { psychological capital. } \\
\text { There is predictive value of } \\
\text { AL for employees' PsyCap }\end{array}$ \\
\hline $\begin{array}{l}\text { Rego, } \\
\text { Sousa, } \\
\text { Marques, } \\
\text { \& Cunha } \\
(2014)\end{array}$ & Cross-sectional & $\begin{array}{l}\text { Hope, positive } \\
\text { affect, authentic } \\
\text { leadership, } \\
\text { employees' } \\
\text { creativity. }\end{array}$ & $\begin{array}{l}\text { Three items for } \\
\text { measuring positive } \\
\text { affect, six items of the } \\
\text { State Hope Scale, five } \\
\text { items for creativity, } \\
16 \text { five-point items } \\
\text { from the ALQ }\end{array}$ & $\begin{array}{l}\text { To investigate whether } \\
\text { (a) positive affect is a } \\
\text { mediator between AL } \\
\text { and creativity, (b) } \\
\text { hope is a mediator } \\
\text { between AL and } \\
\text { creativity, and (c) } \\
\text { hope is a mediator } \\
\text { between positive } \\
\text { affect and creativity }\end{array}$ & $\begin{array}{l}219 \text { employees } \\
\text { working in } \\
\text { Portuguese } \\
\text { retail } \\
\text { organizations } \\
\text { and their } \\
\text { supervisors }\end{array}$ & $\begin{array}{l}\text { AL predicts employees' } \\
\text { creativity, both directly and } \\
\text { through the mediating role of } \\
\text { employees' hope. AL also } \\
\text { predicts employees' positive } \\
\text { affect, which in turn predicts } \\
\text { employees' hope and, } \\
\text { thus, creativity }\end{array}$ \\
\hline $\begin{array}{l}\text { Wang, Sui, } \\
\text { Luthans, } \\
\text { Wang, \& } \\
\text { Wu (2014) }\end{array}$ & Cross-sectional & $\begin{array}{c}\text { AL, } \\
\text { Leader-member } \\
\text { exchange } \\
\text { (LMX), } \\
\text { PsyCap, Job } \\
\text { performance, } \\
\text { gender, age, } \\
\text { education, } \\
\text { organizational } \\
\text { tenure }\end{array}$ & $\begin{array}{l}\text { 16-item ALQ, LMX } \\
\text { 16-item scale, } 24 \text {-item } \\
\text { PsyCap questionnaire, } \\
\text { four items for Job } \\
\text { Performance, } \\
\text { demographics }\end{array}$ & $\begin{array}{l}\text { To investigate the } \\
\text { moderating role of } \\
\text { members' PsyCap and } \\
\text { the mediating role of } \\
\text { leader-member } \\
\text { exchange (LMX) in } \\
\text { influencing the } \\
\text { relationship between } \\
\text { authentic leadership } \\
\text { and members' } \\
\text { performance. }\end{array}$ & $\begin{array}{l}794 \text { members } \\
\text { and their } \\
\text { immediate } \\
\text { leaders }\end{array}$ & $\begin{array}{l}\text { The positive relationship } \\
\text { between AL and job } \\
\text { performance is moderated } \\
\text { by members' PsyCap. } \\
\text { LMX contributes to } \\
\text { members' performance } \\
\text { contingent } \\
\text { upon the members' } \\
\text { PsyCap }\end{array}$ \\
\hline $\begin{array}{l}\text { Roche, } \\
\text { Haar, \& } \\
\text { Luthans } \\
(2014)\end{array}$ & Cross-sectional & $\begin{array}{l}\text { Mindfulness, } \\
\text { PsyCap, } \\
\text { anxiety, } \\
\text { depression, } \\
\text { burnout, age, } \\
\text { education, } \\
\text { firm size }\end{array}$ & $\begin{array}{l}\text { Mindful Attention } \\
\text { Awareness Scale, } \\
\text { 12-item version of the } \\
\text { PCQ, six items for } \\
\text { anxiety and } \\
\text { depression, three } \\
\text { items of the PANAS, } \\
\text { six items from the } \\
\text { Burnout scale, } \\
\text { demographics }\end{array}$ & $\begin{array}{l}\text { To test the direct effect } \\
\text { that the leaders' level } \\
\text { of mindfulness and the } \\
\text { mediating effect of } \\
\text { their psychological } \\
\text { capital may have on } \\
\text { their mental well-being }\end{array}$ & $\begin{array}{l}\text { CEOs/president } \\
\mathrm{s}(\mathrm{n}=205), \\
\text { middle } \\
(\mathrm{n}=183), \\
\text { junior }(\mathrm{n}=202), \\
107 \\
\text { entrepreneurs }\end{array}$ & $\begin{array}{l}\text { Mindfulness was negatively } \\
\text { related to leaders' anxiety, } \\
\text { depression, negative affect and } \\
\text { entrepreneurs' burnout. The } \\
\text { model with PsyCap mediating } \\
\text { the effects of mindfulness on } \\
\text { dysfunctional outcomes } \\
\text { fit the data best }\end{array}$ \\
\hline
\end{tabular}

to predict teachers' self-efficacy and perceived success (Sezgin \& Erdogan, 2015), while changes in the levels of hope in psychotherapists mediated the effect of change in their well-being or their feelings of autonomy in work (Reis \& Hoppe, 2015). Additionally, hope was found to have direct and indirect effects to career variables as well as to life- and job-satisfaction (Badran \& Youssef-Morgan, 2015; Hirschi, 2014). More specifically, hope had a direct effect on college students' proactive career behaviors, which was partially mediated by a greater deal of career planning. Likewise, overall career development attitudes, such as plan- 
ning, decidedness and self-efficacy, mediated the effects of hope on students' life satisfaction. In the same study, hope had an indirect effect to employees' job satisfaction through career decidedness (Hirschi, 2014). Besides, hope, together with optimism, resilience and self-efficacy (i.e., PsyCap), were positively related to employees' job satisfaction (Badran \& Youssef-Morgan, 2015). Along the same lines, in workers with intellectual disability, agency and pathways were mediators in the relationship between career adaptability and life satisfaction (Santilli, Nota, Ginevra, \& Soresi, 2014).

Furthermore, in a vocational training program, hope was positively related to job performance and negatively related to turnover intentions, with trainees' positive affective experiences at work and autonomous goals playing a mediating role (Valero, Hirschi, \& Strauss, 2015). Similarly, hope was found to indirectly predict job performance through work engagement in hotel employees (Karatepe, 2014), while a positive relationship was also found between nurses' psychological capital (i.e., hope, optimism, resiliency, and self-efficacy) and job performance, indicating the importance of improving the positive psychological state of nurses for their retention and effectiveness at work (Sun, Zhao, Yang, \& Fan, 2012). The relationship between psychological capital and job performance as well as employees' task focus and thriving at work was also found in the study of Paterson, Luthans and Jeung (Paterson, Luthans, \& Jeung, 2013). Thriving was positively related to supervisor-rated employee development at work and led to better job performance. Also, the relationship between employees' psychological capital and thriving was mediated by task focus, which was positively related to supervisor's support climate (Badran \& Youssef-Morgan, 2015). In air traffic controllers, for whom safety climate at work plays an important role, it was found that psychological capital enhanced the safety climate (Bergheim et al., 2013).

Thus, hope appears to be significantly related to positive affectivity at the workplace. This is true in the case of further work variables, as well. For example, workers' mindfulness was found to increase their levels of hope, while mindfulness also predicted employees' work engagement and well-being through hope (Malinowski \& Lim, 2015). Overall, these relationships were mediated by positive job-related affect and psychological capital. In particular, mindfulness exerted its positive effect on work engagement by increasing positive affect, hope, and optimism, which both individually and in combination enhanced work engagement. Moreover, employees' hope was positively related to task adaptivity (Strauss, Niven, McClelland, \& Cheung, 2014), while in retail employees' hope appeared as a predictor of creativity with the mediation of positive affect (Rego, Sousa, Marques, \& Cunha, 2012). As Strauss and colleagues (2014) indicated, the employees' levels of hope were positively related to supervisors' ratings of employee task adaptivity and hope had a significant indirect effect on insurance agents' commission via task adaptivity. As far as job procurement self-efficacy among homeless sheltered women was concerned, this 
was positively correlated with hope, although hopeful thinking was not found to predict women's confidence to procure employment beyond the effect of social support (Brown \& Mueller, 2014). In particular, women's job procurement self-efficacy was found to relate positively with hopeful thinking, life satisfaction, social self-efficacy, and the three social support provisions of social integration, reassurance of worth, and guidance. However, neither demographic variables alone nor hopeful thinking, social self-efficacy, and life satisfaction predicted women's self-efficacy in job procurement. On the contrary, the social support provision of social integration predicted homeless women's confidence to procure employment in the future (Brown \& Mueller, 2014).

The results from the third group of studies in the review regarding leadership and its relationship with employees' performance indicated that authentic leadership had a predictive value for employees' psychological capital, overall (Rego, Sousa, Marques, Pina, \& Cunha, 2012). Furthermore, authentic leadership predicted employees' creativity both directly and indirectly through the mediating role of employees' hope (Rego, Sousa, Marques, \& Cunha, 2014) and global psychological capital (Rego, Sousa, Marques, Pina, \& Cunha, 2012). Again, the role of positive affectivity at the workplace was evident, since employees' positive affect was found to predict their levels of hope (Rego, Sousa, Marques, \& Cunha, 2014). Employees' psychological capital was also found to moderate the relationship between authentic leadership and employees' job performance (Wang, Sui, Luthans, Wang, \& Wu, 2014). The relationship between authentic leadership and job performance was greater among members with low rather than high levels of psychological capital. Also, the psychological capital of managers and entrepreneurs was positively correlated with mindfulness, while it was negatively correlated with emotional exhaustion and cynicism (Roche, Haar, \& Luthans, 2014). Particularly, the psychological capital mediated the effects of mindfulness on dysfunctional outcomes, such as anxiety, depression, and negative affect of the leaders, as well as burnout of the entrepreneurs (Roche, Haar, \& Luthans, 2014).

\section{Discussion}

Based on the findings of the twenty-three studies included in this review, it became evident that hope played an important beneficial role in academic and job performance and it was related to several academic- and work-relevant variables. More specifically, hope predicted GPAs, academic achievement, skills and overall positive outcomes in the academic field. According to Snyder and colleagues (Snyder, 1995; Snyder, Lopez, Shorey, Rand, \& Feldman, 2003) any action and behaviour related to academics can be considered as a goal. Our review confirmed that hope, as a cognitive process of combining pathways (planning-related thoughts) and agency (motivation-related thoughts), lays in the heart of the process of pursuing a goal since being successful in the academic tasks requires a combination of planning and motivation (Feldman \& Kubota, 2015). Given the 
nature of hope as a human strength (Valle, Huebner, \& Suldo, 2006), academic performance can be predicted in the short, but also in the long run, a finding that informs interventions for the students' educational development. Furthermore, taking into consideration that the performance of college students could be a predictor of their job performance (Hirschi, Abessolo, \& Froidevaux, 2015), these results are of added value for the career development of college students, since the findings also indicated that the agency component of hope is an important motivational variable for further work achievement (Sung, Turner, \& Kaewchinda, 2011).

These findings support theoretical accounts that career preparation is an important developmental task and that those students who are better prepared for their future careers experience greater well-being (Snyder et al., 2002). Moreover, the findings of Sharabi and colleagues (2016) about the mediation of hope in the relationship between college students' learning disability and online coping avoidance supported the role of hope in predicting the impact of learning disability among students on the internet use for reasons of avoidance. Based on these results, the cultivation of hope in students could also be beneficial in special needs education. Although hope is a rather stable trait of personality (Snyder, 2002), there is increasing evidence that targeted efforts to promote hope can be successful (Gallagher, Marques, \& Lopez, 2017). Hence, the findings of this review suggest that academic personnel should systematically work on building students' hope, as a means to improve academic success and students' overall well-being. Along these lines, the present integrative review reflects the challenges that college students often face by having a simultaneous trainee-employee role (e.g. internships). This joint review on academic and work environments indicates the value of promoting hopeful thinking in college students nowadays, since hope is expected to increase their levels of motivation and engagement in their current and future roles.

Our review also indicated the significant role of hope in job performance, job satisfaction and employees' self-efficacy in different professions and work environments. Depending on the profession, these benefits of hope were related to further positive outcomes. For example, teachers' increased self-efficacy and perceived success were vital to attaining students' success as an ultimate educational priority (Sezgin \& Erdogan, 2015). The hotel employees' high levels of hope were related to their work engagement, which led to better customer services (Karatepe, 2014). Additionally, the agency component of hope was found to increase employees' creativity (Rego, Sousa, Marques, Pina, \& Cunha, 2012). It was also interesting that through hope the career adaptability of workers with intellectual disability led to their life satisfaction (Santilli, Nota, Ginevra, \& Soresi, 2014). In line with previous findings (Reichard, Avey, Lopez, \& Dollwet, 2013), our review suggests that organizations and leaders may boost their employees' positive affect, creativity and productivity more through investing in the employees' willpower and personal resources rather than by paying attention to 
employees' deficits and disabilities. This was also confirmed by the findings regarding the authentic leadership, since the latter was found to enhance employees' psychological capital and self-efficacy, and lead to increased work adaptivity and performance.

Hence, our review encourages future training and hope-development interventions within the work environments, which would facilitate the productivity of the employees by increasing authentic leadership and employees' hope. Additionally, as it was demonstrated in this review, the development of hope at the workplace leads to improved services to the customers (Karatepe, 2014). Thus, such interventions of hope enhancement at the workplace not only will provide psychological and practical benefits for both employees and employers, but they will also be valuable for the customers, as well. Moreover, this review sheds light to the practical value of developing mindfulness and positive affect interventions tailored to the leaders' and managers' needs, as their roles are highly demanding and challenging. Hope-increasing interventions would enable leaders to mitigate the effects of the burnout syndrome and adopt an authentic leadership style in their role.

Should academics and employers be aware of the positive impact of hope on students' and employees' achievements, then they could provide a wider context to promote hopeful thinking. The role of the wider context also emerged in the findings about homeless women's expected capabilities to being employed in the future. Hope did not predict homeless women's confidence in their ability to procure employment beyond the social support. On the contrary, social integration assumed a more critical role to homeless women's self-efficacy for securing employment than the intrapersonal process of hopeful thinking (Brown \& Mueller, 2014). Given that the cognitive process of hope often involves some external agency (e.g. family, peers, or a spiritual being) in generating plans for pursuing goals (Bernardo, 2010; Scioli, Ricci, Nyugen, \& Scioli, 2011), these results encourages future research on how the wider social support may contribute to hope development towards goal attainment, especially in disadvantaged individuals at a time of economic crisis.

Notwithstanding the integrative empirical support from the studies about hope in academic and work environments, some methodological limitations should be considered in our review. First, almost all of the studies both in academics and workplace were cross-sectional ones, except one that was longitudinal across four years of university attendance, which however had an ethnically homogenous sample. Thus, the respective empirical evidence about the role of hope in a long run, remains limited. Future research may address this need for longitudinal studies on hope with regard to academic and work tasks. Additionally, the findings about hope being related to career development leave space for future research on the types of skills that may be related to helping students on how to identify and move along alternative pathways. With regard to the role of hope in the workplace, the samples of the studies represented only some of the 
various professions, while the participants were ethnically specific. More studies could be conducted in several different professions, taking also into account the individuals' demographic variables along with the wider conditions of the workplace. The potential role of the wider context, in terms of social integration, social adjustment and social support pertains as an additional area of future research with regard to the role of hope in relation to academic and work variables. Lastly, further research into hope-cultivating interventions that could fit in the different needs of academic and work environments is warranted.

\section{References}

Badran, A. M., \& Youssef-Morgan, C. M. (2015). Psychological Capital and Job Satisfaction in Egypt. Journal of Managerial Psychology, 30, 354-370.

https://doi.org/10.1108/JMP-06-2013-0176

Bergheim, K., Eid, J., Hystad, S. W., Nielsen, M. B., Mearns, K., Larsson, G., \& Luthans, B. (2013). The Role of Psychological Capital in Perception of Safety Climate among Air Traffic Controllers. Journal of Leadership \& Organizational Studies, 20, 232-241. https://doi.org/10.1177/1548051813475483

Bernardo, A. B. (2010). Extending Hope Theory: Internal and External Locus of Trait Hope. Personality and Individual Differences, 49, 944-949. https://doi.org/10.1016/j.paid.2010.07.036

Brown, C., \& Mueller, C. T. (2014). Predictors of Employment among Sheltered Homeless Women. Community, Work \& Family, 17, 200-218. https://doi.org/10.1080/13668803.2014.890562

Chang, E. C. (1998). Hope, Problem-Solving Ability, and Coping in a College Student Population: Some Implications for Theory and Practice. Journal of Clinical Psychology, 54, 953-962. https://doi.org/10.1002/(SICI)1097-4679(199811)54:7<953::AID-JCLP9>3.0.CO;2-F

Day, L., Hanson, K., Maltby, J. Proctor, C., \& Wood, A. M. (2010). Hope Uniquely Predicts Objective Academic Achievement above Intelligence, Personality, and Previous Academic Achievement. Journal of Research in Personality, 44, 550-553. https://doi.org/10.1016/j.jrp.2010.05.009

Drysdale, M., \& McBeath, M. (2014). Exploring Hope, Self-Efficacy, Procrastination, and Study Skills between Cooperative and Non-Cooperative Education Students. Asia-Pacific Journal of Cooperative Education, 15, 69-79.

Erikson, E. H. (1950). Childhood and Society. New York: Norton.

Feldman, D. B., \& Kubota, M. (2015). Hope, Self-Efficacy, Optimism, and Academic Achievement: Distinguishing Constructs and Levels of Specificity in Predicting College Grade-Point Average. Learning and Individual Differences, 37, 210-216. https://doi.org/10.1016/j.lindif.2014.11.022

Gallagher, M. W., Marques, S. C., \& Lopez, S. J. (2017). Hope and the Academic Trajectory of College Students. Journal of Happiness Studies, 18, 341.

https://doi.org/10.1007/s10902-016-9727-z

Hirschi, A. (2014). Hope as a Resource for Self-Directed Career Management: Investigating Mediating Effects on Proactive Career Behaviors and Life and Job Satisfaction. Journal of Happiness Studies, 15, 1495-1512. https://doi.org/10.1007/s10902-013-9488-x

Hirschi, A., Abessolo, M., \& Froidevaux A. (2015). Hope as a Resource for Career Explo- 
ration: Examining Incremental and Cross-Lagged Effects. Journal of Vocational Behavior, 86, 38-47. https://doi.org/10.1016/j.jvb.2014.10.006

Karatepe, M. O. (2014). Hope, Work Engagement, and Organizationally Valued Performance Outcomes: An Empirical Study in the Hotel Industry. Journal of Hospitality Marketing \& Management, 23, 678-698. https://doi.org/10.1080/19368623.2014.855994

Malinowski, P., \& Lim, H. J. (2015). Mindfulness at Work: Positive Affect, Hope, and Optimism Mediate the Relationship between Dispositional Mindfulness, Work Engagement, and Well-Being. Mindfulness, 6, 1250-1262.

https://doi.org/10.1007/s12671-015-0388-5

Michael, S. T. (2000). Hope Conquers Fear: Overcoming Anxiety and Panic Attacks. In C. R. Snyder (Ed.), Handbook of Hope: Theory, Measures, and Applications (pp. 301-319). New York: Academic Press. https://doi.org/10.1016/B978-012654050-5/50018-X

Mowrer, O. H. (1960). Learning Theory and Behavior. New York, NY: Wiley. https://doi.org/10.1037/10802-000

Paterson, A. T., Luthans, F., \& Jeung, W. (2013). Thriving at Work: Impact of Psychological Capital and Supervisor Support. Journal of Organizational Behavior, 35, 434-446. https://doi.org/10.1002/job.1907

Peterson, C., \& Seligman, M. E. P. (2004). Character Strengths and Virtues: A Handbook and Classification. New York, NY: Oxford University Press.

Peterson, S. J., \& Byron, K. (2008). Exploring the Role of Hope in Job Performance: Results from Four Studies. Journal of Organizational Behavior, 29, 785-803.

https://doi.org/10.1002/job.492

Pruyser, P. W. (1987). Maintaining Hope in Adversity. Bulletin of the Menninger Clinic, 51, 463-474.

Rego, A., Sousa, F., Marques, C., \& Cunha, M. P. (2012). Authentic Leadership Promoting Employees' Psychological Capital and Creativity. Journal of Business Research, 65, 429-437. https://doi.org/10.1016/j.jbusres.2011.10.003

Rego, A., Sousa, F., Marques, C., \& Cunha, M. P. (2014). Hope and Positive Affect Mediating the Authentic Leadership and Creativity Relationship. Journal of Business Research, 67, 200-210. https://doi.org/10.1016/j.jbusres.2012.10.003

Rego, A., Sousa, F., Marques, C., Pina, E., \& Cunha, M. P. (2012). Retail Employees' Self-Efficacy and Hope Predicting Their Positive Affect and Creativity. European Journal of Work and Organizational Psychology, 21, 923-945. https://doi.org/10.1080/1359432X.2011.610891

Reichard, J. R., Avey, B. J., Lopez, S., \& Dollwet, M. (2013). Having the Will and Finding the Way: A Review and Meta-Analysis of Hope at Work. The Journal of Positive Psychology, 8, 292-304. https://doi.org/10.1080/17439760.2013.800903

Reis, D., \& Hoppe, A. (2015). Change in Affective Well-Being on Change in Perceived Job Characteristics: The Mediating Role of Hope. Journal of Occupational and Organizational Psychology, 88, 19-40. https://doi.org/10.1111/joop.12076

Roche, M., Haar, J. M., \& Luthans, F. (2014). The Role of Mindfulness and Psychological Capital on the Well-Being of Leaders. Journal of Occupational Health Psychology, 19, 476-489. https://doi.org/10.1037/a0037183

Santilli, S., Nota, L., Ginevra, M. C., \& Soresi, S. (2014). Career Adaptability, Hope and Life Satisfaction in Workers with Intellectual Disability. Journal of Vocational Behavior, 85, 67-74. https://doi.org/10.1016/j.jvb.2014.02.011

Scioli, A., Ricci, M., Nyugen, T., \& Scioli, E. R. (2011). Hope: Its Nature and Measure- 
ment. Psychology of Religion and Spirituality, 3, 78-97.

https://doi.org/10.1037/a0020903

Sezgin, F., \& Erdogan, O. (2015). Academic Optimism, Hope and Zest for Work as Predictors of Teacher Self-Efficacy and Perceived Success. Educational Sciences: Theory \& Practice, 15, 7-19. https://doi.org/10.12738/estp.2015.1.2338

Sharabi, A., Sade, S., \& Margalit, M. (2016). Virtual Connections, Personal Resources, Loneliness, and Academic Self-Efficacy among College Students with and without LD. European Journal of Special Needs Education, 31, 376-390. https://doi.org/10.1080/08856257.2016.1141542

Snyder, C. R. (1994). Hope and Optimism. Encyclopedia of Human Behavior, 2, 535-542.

Snyder, C. R. (1995). Conceptualizing, Measuring, and Nurturing Hope. Journal of Counseling and Development, 73, 355-360. https://doi.org/10.1002/j.1556-6676.1995.tb01764.x

Snyder, C. R. (2002). Hope Theory: Rainbows in the Mind. Psychological Inquiry, 13, 249-275. https://doi.org/10.1207/S15327965PLI1304_01

Snyder, C. R., Cheavens, J., \& Michael, S. T. (1999). Hoping. In C. R. Snyder (Ed.), Coping: The Psychology of What Works (pp. 205-231). New York, NY: Oxford University Press.

Snyder, C. R., Harris, C., Anderson, J. R., Holleran, S. A., Irving, L. M., Sigmon, S. T., \& Harney, P. (1991). The Will and the Ways: Development and Validation of an Individual-Differences Measure of Hope. Journal of Personality and Social Psychology, 60, 570-585. https://doi.org/10.1037/0022-3514.60.4.570

Snyder, C. R., LaPointe, A. B., Jeffrey Crowson, J., \& Early, S. (1998). Preferences of Highand Low-Hope People for Self-Referential Input. Cognition \& Emotion, 12, 807-823. https://doi.org/10.1080/026999398379448

Snyder, C. R., Lopez, S. J., Shorey, H. S., Rand, K. L., \& Feldman, D. B. (2003). Hope Theory, Measurements, and Applications to School Psychology. School Psychology Quarterly, 18, 122-139. https://doi.org/10.1521/scpq.18.2.122.21854

Snyder, C. R., Shorey, H. S., Cheavens, J., Pulvers, K. M., Adams, V. H., \& Wiklund, C. (2002). Hope and Academic Success in College. Journal of Educational Psychology, 94, 820-826. https://doi.org/10.1037/0022-0663.94.4.820

Stotland, E. (1969). The Psychology of Hope. San Francisco, CA: Jossey-Bass.

Strauss, K., Niven, K., McClelland, C., \& Cheung, B. (2014). Hope and Optimism in the Face of Change: Contributions to Task Adaptivity. Journal of Business Psychology, 30, 733-745. https://doi.org/10.1007/s10869-014-9393-2

Sun, T., Zhao, X. W., Yang, L. B., \& Fan, L. H. (2012). The Impact of Psychological Capital on Job Embeddedness and Job Performance among Nurses: A Structural Equation Approach. Journal of Advanced Nursing, 68, 69-79. https://doi.org/10.1111/j.1365-2648.2011.05715.x

Sung, Y., Turner, L. S., \& Kaewchinda, M. (2011). Career Development Skills, Outcomes, and Hope among College Students. Journal of Career Development, 40, 127-145. https://doi.org/10.1177/0894845311431939

Valero, D., Hirschi, A., \& Strauss, K. (2015). Hope in Adolescent Careers: Mediating Effects of Work Motivation on Career Outcomes in Swiss Apprentices. Journal of Career Development, 42, 381-395. https://doi.org/10.1177/0894845314566866

Valle, M. F., Huebner, E. S., \& Suldo, S. M. (2006). An Analysis of Hope as a Psychological Strength. Journal of School Psychology, 44, 393-406.

https://doi.org/10.1016/j.jsp.2006.03.005 
Wang, H., Sui, Y., Luthans, F., Wang, D., \& Wu, Y. (2014). Impact of Authentic Leadership on Performance: Role of Followers' Positive Psychological Capital and Relational Processes. Journal of Organizational Behavior, 35, 5-21.

https://doi.org/10.1002/job.1850

Woodbury, C. A. (1999). The Relationship of Anxiety, Locus of Control and Hope to Career Indecision of African American Students. Dissertation Abstracts International, 59, 4072. 